\title{
Efektivitas Program Keluarga Harapan (PKH) Terhadap Penerima Bantuan di Desa Laliko Kecamatan Campalagian Kabupaten Polewali Mandar
}

\author{
Rahmah Muin, Rosdiana \\ Prodi Hukum Ekonomi Syariah, Fakultas Agama Islam, Universitas Al Asyariah Mandar \\ rahmah_muin@mail.unasman.ac.id
}

\begin{abstract}
Abstrak
Penelitian ini adalah kualitatif deskriptif yang bertujuan untuk menggambarkan, meringkas berbagai kondisi dan mengangkat fenomena ke kepermukaan sebagai suatu ciri, karakter, model, atau gambaran mengenai situasi, kondisi, ataupun fenomena tertentu. Lokasi penelitian ini bertempat di Desa Laliko Kecamatan Campalagian. Sumber data yang digunakan yaitu sumber data primer dan sumber data sekunder. Metode pengumpulan data diperoleh dari obsevasi, wawancara mendalam, dokumentasi, dan studi kepustakaan. Teknik pengolahan dan analisis data terdiri dari 3 (tiga) tahapan yaitu reduksi data, penyajian data, dan penarikan kesimpulan atau verifikasi. Pengujian keabsahan data menggunakan kritria kredibilitas melalui teknik pemeriksaan berupa triangulasi. Hasil penelitian ini menunjukkan bahwa efektivitas Program Keluarga Harapan (PKH) terhadap penerima bantuan di Desa Laliko, dapat membantu dalam mengurangi beban pengeluaran masyarakat namun demikian PKH ini belum bisa dikatakan sepenuhnya efektif dalam hal penanggulangan kemiskinan dan meningkatkan pendapatan masyarakat dilihat dari indikator perubahan nyata yang dialami masyarakat. Adapun hambatan dalam pelaksanaan program keluarga harapan ialah belum tercapainya tujuan dari PKH karena masih adanya penerima bantuan yang mempergunakan dana yang diterimanya diluar dari ketentuan PKH karena alasan tertentu. Selain itu, jika dilihat dari hasil penelitian terdapat sebagian masyarakat mulai terus menerus menghrapkan bantuan dana PKH sehingga dikhawatirkan dapat merubah pola pikir mereka dalam menciptakan perilaku kemandirian. PKH diharapkan mampu mengurangi angka kemiskinan dan meningkatkan pendapatan keluarga miskin. Implikasi penelitian ini yaitu penerima manfaat seharusnya punya kesadaran lebih mengenai dana PKH ini semestinya digunakan sesuai yang dipersyaratkan sehingga uang yang diterima tidak tidak dibelanjakan begitu saja.
\end{abstract}

Kata Kunci: perbankan syari'ah, sengketa syari'ah, pengadilan agama

\section{PENDAHULUAN}

Kemiskinan adalah bentuk masalah utama yang ada dalam kehidupan masyarakat, khususnya pada masyarakat di Negara berkembang seperti Indonesia. Indonesia masih dikatakan sebagai negara berkembang karena masih dalam proses pembangunan terutama di bidang ekonomi. Namun, krisis moneter yang dialami pada tahun 1997 telah memperburuk kondisi sosisal ekonomi yang membuat Indonesia jatuh ke dalam kemiskinan yang lebih serius dan berakibat pada penurunan kualitas kehidupan masyarakat seperti rendahnya 
tingkat kesehatan, penurunan gizi, dan keterbelakangan pendidik. Kemiskinan juga diartikan sebagai suatu keadaan dimana seseorang tidak sanggup memelihara dirinya sendiri sesuai dengan taraf kehidupan kelompok dan juga mampu memanfaatkan tenaga mental, maupun fisiknya dalam kelompok tersebut. Kemiskinan diukur dari tingkat pendapatan dan kebutuhan pokok minimal suatu Negara, yang akan berbeda antara Negara satu dengan Negara lainnya. ${ }^{1}$

Kemiskinan dalam pandangan Islam bukan hanya sekedar ketidakmampuan dalam memenuhi kebutuhan dasar akan tetapi kemiskinan merupakan salah satu masalah kultural dimana seseorang menjadi miskin karena perilaku buruknya seperti malas untuk bekerja dan berusaha. Tujuan hukum Islam adalah kemashlahatan hidup mkanusia, baik rohani maupun jasmani, individual dan sosial. Kemashlahatan itu tidak hanya di dunia saja tetapi juga untuk kehidupan yang kekal diakhirat kelak. Tujuan hukum Islam dapat dilihat dari dua segi yaitu segi Pembuatan Hukum Islam yang bertujuan untuk memenuhi keperluan hidup manusia yang bersifat primer, sekunder dan tersier. Dari segi pelaku hukum Islam yakni manusia sendiri, yaitu untuk mencapai kehidupan yang berbahagia dan sejahtera. ${ }^{2}$

Program Keluarga Harapan (PKH) lebih ditujukan sebagai upaya untuk membangun sistem perlindungan sosial terhadap masyarakat miskin. Melihat dari pengalaman yang telah dialami negara-negara lain, PKH ini sangat bermanfaat terutama bagi keluarga dengan tingkat kemiskinan yang sangat tinggi. Adanya PKH di Indonesia diharapkan akan mampu membantu keluarga sangat miskin yang lebih memerlukan bantuan dari siapapun itu. ${ }^{3}$

Beberapa penelitian yang pernah dilakukan sebelumnya menunjukkan bahwa PKH dapat membantu masyarakat keluar dari kemiskinan, meningkatkan konsumsi keluarga, bahkan pada skala yang lebih luas. Hal ini sesuai dengan tujuan PKH dalam meningkatkan kesejahteraan masyarakat.

Berdasarkan yang telah dijelaskan diatas, peneliti tertarik mengangkat judul penelitian tentang "Efektivitas Program Keluarga Harapan (PKH) Terhadap Penerima Bantuan Di Desa Laliko Kecamatan Campalagian Kabupaten Polewali Mandar”.

\section{TINJAUAN PUSTAKA}

\section{A. Konsep Efektivitas}

\footnotetext{
${ }^{1}$ M. Nur Rianto Al Arif, Teori Makro ekonomi Islam konsep, teori, dan analisis, (Bandung Penerbit Alfabeta, 2010), h.255

${ }^{2}$ Mohammad Daud Ali , Hukum Islam, (Jakarta: Rajawali Pers, 2009), h. 6162

${ }^{3}$ Evi Fitriah "Implementasi Program Keluarga Harapan (PKH) Dalam Pengentasan Kemiskinan” Skripsi (Serang: Universitas Sultan Ageng Tirtayasa, 2010), h.16
} 
Efektiv merupakan kemampuan seseorang mengerjakan sesuatu dengan benar, efektivitas sangat berhubungan dengan tujuan karena semakin dekat organisasi dengan tujuannnya, maka organisasi itu semakin efektiv. Ada banyak pendapat mengenai arti dari efektivitas, seringkali terjadi perbedaan pendapat dkarenakan kerangka yang digunakan berbeda. Richard M. Steers mengungkakan bahwa efektivitas dapat dinilai berdasarkan ukuran mengenai sejauh mana keberhasilan suatu organisasi dalam dengan tujuan yang akan dicapai. ${ }^{4}$

Subagyo berpendapat dalam jurnal ekonomi dan sosial mengatakan bahwa efektivitas merupakan kecocokan antara output dengan tujuan yang telah ditentukan sebelumnya. Efektivitas merupakan suatu kondisi yang terjadi apabila diinginkan. Jika individu menghendaki untuk melakukan suatu pekerjaan dengan tujuan tertentu, Maka yang dikerjakan tersebut bisa dibilang efektiv apabila muncul suatu akibat atau memiliki tujuan sesuai dengan yang diinginkan sebelumnya. ${ }^{5}$

Menurut Sutrisno Efektivitas dari suatu program ataupun kegiatan yang dilaksanakan dilihat dari kesesuaian antara tujuan dan realisasi program dapat diukur dengan menggunakan 5 indikator yaitu sebagai berikut: ${ }^{6}$

1. Pemahaman Program

Pemahaman program adalah indikator yang digunakan untuk mengukur seberapah jauh pengetahuan masyarakat tentang Program Keluarga Harapan. Pemahaman program terhadap masyarakat dapat dilakukan melalui kegiatan sosialisasi. Hal yang sangat penting untuk diperhatikan dalam kegiatan sosialisasi merupakan kemampuan dari penyelenggara program pada saat menyampaikan sosialisasi kegiatan yang dilaksanakan agar informasi tentang pelaksanaan suatu program bisa dipahami oleh masyarakat dengan mudah, terkhusus bagi rumah tangga penerima bantuan.

2. Ketepatan Sasaran

Ketepatan sasaran adalah faktor penting dalam proses pelaksanaan program, karena memberikan tolak ukur mengenai program yang sudah dilaksanakan, sehingga kita dapat mengetahui berhasil atau tidaknya program tersebut. Tepat sasaran, PKH hanya diberikan kepada keluarga yang datanya bersumber dari Desa. Sasaran dari PKH yaitu masyarakat miskin yang telah dinyatakan lolos untuk menerima bantuan PKH.

3. Ketepatan waktu

${ }^{4}$ Richard M. Strees, Efektivitas Organisasi, (Jakarta: Lembaga Pendidikan dan Pembinaan Manajemen dan Erlangga, 1980), h. 5

${ }^{5} \mathrm{Ni}$ Wayan Budiani "Efektvitas Program Penaggulangan Penangguran Pengangguran Karang Taruna (Eka Taruna Bhakti) Desa Sumerta Kelod Kecamatan Denpasar Timur kota Denpasar" Jurnal Ekonomi dan Sosial INPUT , Vol. 2, No. 1, h. 52

${ }^{6}$ Urika Tri Astari dan Argo Pambudi, Efektivitas Program Keluarga Harapan di Kecamatan Pandak Bantul, Artikel diakses 28 Februari 2020 dari http://journal.student.uny.ac.id 
Ketepatan waktu dalam pencairan bantuan PKH sangat dibutuhkan, mengingat bantuan sosial yang diberikan setiap tiga bulan sekasli, kepada masing-masing penerima PKH.

\section{Tercapainya Tujuan}

Tujuan adalah capaian dari suatu sasaran dan target yang dislaksanakan melalui beberapa tahapan yang telah ditentukan, sehingga memberikan arahan terkait sasaran yang ingin dicapai. Program Keluarga Harapan memiliki tujuan yaitu meningkatkan pelayanan pendidikan bagi anak dan pelayanan kesehatan untuk meningkatkat kesejahteraan sosial bagi keluarga miskin (jangka panjang), serta membantu mengurangi beban pengeluaran masyarakat miskin (jangka pendek).

\section{Perubahan Nyata}

Perubahan nyata adalah suatu bentuk perubahan yang dirasakan oleh seseorang atau kelompok terkait pelaksanaan kegiatan atau program yang telah dilaksanakan. Perubahan nyata bisa berdampak positif maupun berdampak negatif, tergantung dari proses pelaksanaan yang diterapkan oleh pihak-pihak yang terkait, sehingga kegiatan yang dilaksnakan dapat berjalan berdasarkan ketentuan yang telah diterapkan.

\section{B. Program Keluarga Harapan (PKH)}

Program Keluarga Harapan atau yang lebih yang dikenal dengan PKH merupakan suatu program bantuan sosial kepada masyarakat miskin yang telah lulus kualifikasi berdasarkan persyaratan-persyaratan tertentu dengan maksud untuk memberikan perubahan pola pikir masyarakat. PKH juga merupakan salah satu program bantuan sosial dengan memberikan sejumlah uang tunai bagi Rumah Tangga Sangat Miskin (RTSM) dan mereka diharuskan untuk memenuhi ketentuan serta persyaratan yang ditetapkan sebelumnya. Secara internasional PKH dikenal sebagai program Bantuan Tunai Bersyarat atau program conditional cash transfers (CCT). Persyaratan seperti kehadiran di fasilitas kesehatan bagi ibu hamil atau anak balita dan kehadiran di fasilitas pendidikan bagi anak usia sekolah. ${ }^{7}$

Keluarga Penerima bantuan yang disebut Keluarga Penerima Manfaat merupakan keluarga penerima bantuan sosial PKH yang memenuhi syarat persyaratan. Bantuan Sosial PKH yaitu pemberian bantuan dengan memberikan sejumlah uang tunai bagi masyarakat maupun keluarga sangat miskin, yang dinyatakan tidak mampu memenuhi kebutuhan hidupnya. PKH ini didasari oleh Peraturan Menteri Sosial Republik Indonesia Nomor 1 Tahun 2018 mengenai Program Keluarga Harapan (PKH) yang tecantum didalam Bab 1 Ketentuan Umum pada pasal 1.

Misi dari Program Keluarga Harapan yaitu mengupayakan adanya perubahan pola pikir dan perilaku bagi penerima manfaat untuk kesehatan anak dan ibu hamil serta untuk meningkatkan pendidikan bagi anak-anak masyarakat sangat miskin. Suatu kebijakan dan

${ }^{7}$ Kementerian Sosial Republik Indonesian, Pedoman Umum Penyelenggaraan Program Keluarga Harapan, 2013, h. 4-5 
misi yang baik terkadang tidak selaras dengan apa yang menjadi harapan dan kenginan yang ingin dicapai, terakadang juga secara strukttural dapat memiskinkan masyarakat. Hal itu bisa terjadi apabila tidak tepatnya sasaran kebijakan yang dilakukan oleh pemerintah, misal adanya masyarakat miskin yang terkadang menggunakan bantuan tunai yang diterima dipergunakan untuk konsumsi kebutuhan hidupnya sehari-hari, bukan untuk pendidkan dan kesehatan. Oleh karena itu, Program penanggulangan kemiskinan perlu penanganan yang lebih dan terpadu serta berkelanjutan. ${ }^{8}$

Adapun yang tolak ukur dari sasaran penerima PKH yaitu masyarakat miskin yang rentan terdaftar didalam data terpadu program penanganan kemiskinan, memiliki komponen pendidikan, kesehatan, dan kesejahteraan sosial. Hal ini berlandaskan pada Peraturan Menteri Sosial Republik Indonesia Nomor 1 Tahun 2018 mengenai Program Kelurga Harapan (PKH).

Adapun tujuan Program PKH sebagaimana yang tercamtum dalam Peraturan Menteri Sosial RI Nomor 1 Tahun 2018 mengenai Program Kelurga Harapan (PKH) yang tecantum dalam Bab 1 Ketentuan Umum pada pasal 2 sebagai berikut bahwa PKH bertujuan untuk meningkatkan taraf hidup Keluarga Penerima Manfaat melalui akses layanan pendidikan, kesehatan, dan kesejahteraan sosial. Program PKH juga bertujuan mengurangi beban pengeluaran dan meningkatkan pendapatan keluarga miskin dan rentan, termasuk menciptakan perubahan perilaku dan kemandirian Keluarga Penerima manfaat dalam mengakses layanan kesehatan dan pendidikan serta kesejahteraan sosial.

Mengenai Program Keluarga Harapan pertama kali diterapkan di Desa Laliko kecamatan Campalagian yaitu pada tahun 2012. Petugas PKH di Kecamatan Campalagian terdiri dari 2 orang yaitu koordinator data yang tugasnya melakukan pengelolaan dan pengiriman data hasil validasi calon penerima, hasil verifikasi komitmen dan hasil pemutakhiran kepesertaan serta realisasi penyaluran bantuan sesuai dengan ketentuan dan jadwal yang telah disepakati. Sedangkan pendamping PKH bertugas dalam menyiapkan data dan undangan bagi calon penerima Program, menyiapkan berbagai fasilitas tempat pertemuan dan sarana yang dibutuhkan dan membuat daftar hadir pertemuan melakukan koordinasi dengan aparat setempat untuk menetapkan waktu.

\section{Penaggulangan Kemiskinan}

Kemiskinan merupakan dampak yang sangat nyata didalam kehidupan masyarakat terutama bagi keluarga sangat miskin baik diukur dari segi kemampuan perekonomian, pendidikan maupun kesehatan berupa pemenuhan kebutuhan gizi dan nutrisi yang dapat memicu akan rendahnya sumber daya manusia. Kemiskinan juga merupakan fenomena sosial struktural yang berdampak krusial bagi keberhasilan pembangunan. Amartya Sen

${ }^{8}$ Kementerian Sosial Republik Indonesian, Pedoman Umum Penyelenggaraan Program Keluarga Harapan, 2013, h. 10 
mengemukakan bahwa seseorang dikatakan miskin apabila mereka tidak dapat melakukan sesuatu dan bukan karena mereka tidak mempunyai sesuatu. Menurut Yeni Salma Barlinti didalam tulisannya mengenai "Konsep Zakat dalam Sustainable Development: Suatu kajian Terhadap UU Pengelolaan Zakat" mengatakan bahwa kemiskinan merupakan salah satu kondisi dimana seseorang belum mampu memenuhi taraf kehidupannya.

Shirazi dan Pramanik berpendapat bahwa kemiskinan diartikan juga sebagai suatu keadaan yang dihadapi oleh seseorang, dimana mereka tidak mempunyai cukup sumber daya dalam memenuhi kebutuhan hidup yang lebih baik, hal ini dapat dilihat dari segi ekonomi, psikologis, social, maupun spiritual. BKKBN (Badan Koordinasi Keluarga Berencana Nasional) juga berpendapat bahwa kemiskinan merupakan kondisi dimana seseorang tidak mampu memelihara dirinya dalam taraf kehidupan dan juga tidak sanggup memanfaatkan tenaga, mental ataupun fisiknya dalam pemenuhan kebutuhan hidupnya. ${ }^{9}$

Terdapat beberapa ayat Al-qur'an yang berbicara tentang tentang jaminan sosial yang menyuruh kaum muslimin untuk saling tolong-menolong saudara mereka yang fakir dan miskin yang tiak mampu memenuhi kebutuhan hidupnya, terdapat dalam surah Al-Hasyr ayat 7 dibawah ini

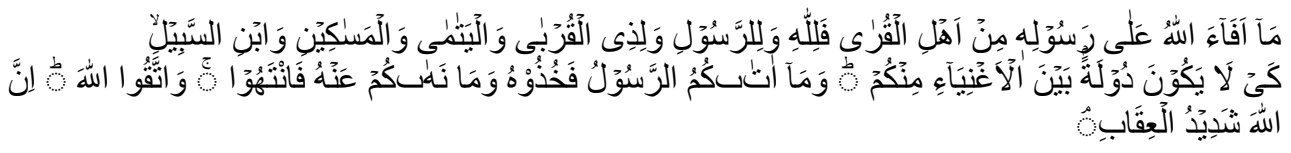

Terjemahnya:

"Apa saja harta rampasan (fai-i) yang diberikan Allah kepada RasulNya (dari harta benda) yang berasal dari penduduk kota-kota Maka adalah untuk Allah, untuk rasul, kaum kerabat, anak-anak yatim, orang-orang miskin dan orang-orang yang dalam perjalanan, supaya harta itu jangan beredar di antara orang-orang Kaya saja di antara kamu. apa yang diberikan Rasul kepadamu, Maka terimalah. dan apa yang dilarangnya bagimu, Maka tinggalkanlah. dan bertakwalah kepada Allah. Sesungguhnya Allah Amat keras hukumannya"

Dari ayat diatas dijelaskan bahwa negara Islam, dalam kedudukannya sebagai wali bagi orang-orang miskin an mereka yang bertanggung jawab menyediakan kebutuhan paling dasar bagi warga nearanyayang fakir dan miskin. Di dalam penerimaan negara yang berasal dari fai', Al-Qur'an dengan khusus menyebutkan bagian kaum fakir dan miskin, selain menetapkan negara Islam bertangung jawab untuk mencukupi kaum miskin, Islam juga menyuruh pemeluknya yang kaya untuk menolong kerabat, sahabat dan tetangga mereka yang membutuhkan bantuan.

Program penanggulangan kemiskinan merupakan suatu kegiatan yang dilaksanakan pemerintah pusat ataupun daerah, dunia usaha, serta masyarakat dalam meningkatkan kesejahteraan masyarakat sangat miskin dengan bantuan sosial, pemberdayaan masyarakat, pemberdayaan usaha makro ekonomi ndan mikro, serta program lainnya.

${ }^{9}$ Adrianus Meliala, Masalah Kemiskinan dan Kejahatan serta Respon Kebijakan Publik dalam Rangka Mengatasinya, Ed. 8, (Kebijakan Publik, 2012), h. 9 
Strategi penanggulangan kemiskinan dirumuskan menjadi 4 (empat) startegi utama sebagai berikut: ${ }^{10}$

1. Memperbaiki program perlindungan sosial

Sistem perlindungan sosial yang bertujuan membantu individu maupun masyarakat agar lebih siap dalam menghadapi goncangan-goncangan yang terjadi didalam kehidupan misalnya kehilangan pekerjaan, ditimpa bencana, jatuh sakit, , dan lainnya.

2. Meningkatkan akses terhadap pelayanan dasar

Bentuk peningkatan akses pelayanan dasar penduduk miskin yaitu meningkatnya akses dibidang kesehatan, pendidikan, sanitasi, air bersih, serta pangan dan gizi yang dapat membantu dalam mengurangi biaya yang dikeluarkan oleh masyarakat miskin.

3. Pemberdayaan kelompok masyarakat miskin

Pemberdayaan kelompok merupakan upaya yang sangat penting dilakukan untuk meningkatkan efektivitas dalam penanggulangan kemiskinan bagi masyarakat miskin.

4. Menciptakan pembangunan yang inklusif

Pembangunan yang inklusif dimaksudkan sebagai pembangunan yang mengikutsertakan dan memberikan manfaat kepada seluruh masyarakat

\section{METODE PENELITIAN}

\section{A. Jenis dan Lokasi Penelitian}

Jenis penelitian yang digunakan oleh peneliti pada penulisan ini merupakan peneltian kualitatif yaitu bentuk penelitian secara kontekstual dengan menjadikan manusia instrumen yang disesuaikan dengan kondisi maupun situasi yang wajar dalam keterkaitannya dengan pengumpulan data yang umumnya bersifat kualitatif. ${ }^{11}$ Penelitian ini adalah jenis penelitilan sosial dengan menggunakan deskriptif kualitatif. Menurut Whitney yang dikutip Muh Khalifah Mustamin mengemukakan bahwa penelitian deskriptif kualitatif merupakan pencarian fakta dengan interpensi yang tepat, penelitian deskriptif mempelajari mengenai permasalah yang ada di masyarakat. ${ }^{12}$ Adapun lokasi atau tempat penelitian yang akan diteliti yaitu di Desa Laliko Kecamatan Campalagian Kabupaten Polewali.

\section{B. Pendekatan Penelitian}

Pendekatan penelitian yang digunakan pada skripsi ini yaitu pendekatan keilmuan untuk membahas objek penelitian. Pendekatan keilmuan yang penulis maksud yaitu ilmu kesejahteraan sosial. Ilmu kesejahteraan sosial merupakan ilmu terapan yang mengkaji dan

${ }^{10}$ Peraturan Presiden Republik Indonesia No. 15 Tahun 2010 tentang Percapatan PenanggulanganKemiskinan.http://www.bphn.go.id/data/documents/10pr015.pdf, Diakses (4 April 2020)

${ }^{11}$ Lexy. J.Moleong, Metodologi Penelitian Kualitatif, (Bandung: Rosdakarya, 2002), h.3

${ }^{12}$ Muh. Khalifah Mustamin, Metodologi Penelitian Pendidikan, (Makassar: Alauddin Press 2009), h. 19 
mengembangkan kerangka pemikiran, serta metodologi yang dapat digunakan untuk meningkatkan kualitas hidup bagi masyaraka ${ }^{13}$

\section{Sumber Data dan Metode Pengumpulan Data}

Sumber data yang digunakan untuk mengumpulkan data-data dalam penelitian iniyaitu sumber data primer dan data sekunder. Data primer merupakan data yang secara langsung diperoleh di lapangan untuk digunakan dalam mendukung penelitian ini. Cara mengumpulkan data primer adalah melakukan observasi dan wawancara dengan informan yang ditentukan sebelumnya oleh penulis. Adapun informan yang penulis tentukan untuk memperoleh sumber data primer yaitu pendamping PKH dan penerima bantuan PKH di Desa Laliko. Sementara Data sekunder adalah data sumber kedua yang didapatkan melalui bukubuku, artikel, brosur, yang diperoleh dari website yang berhubungan alam penelitian ini. Untuk melengkapi data primer yang telah dikumpulkan diperoleh dari dokumentasi dan studi kepustakaan yang berkaitan dengan masalahan yang diteliti yaitu bersumber dari profil Desa Laliko serta dokumen yang berkaitan dengan Program Keluarga Harapan (PKH) di Desa Laliko Kecamatan Campalagian.

Adapun Metode pengumpulan data yang digunakan dalam penelitian ini adalah Observasi, Wawancara, Dokumentasi dan Studi Kepustakaan.

Instrumen yang digunakan untuk memperoleh data primer pada penelitian ini yaitu wawancara dengan beberapa item pertanyaan yang disiapkan sebelumnya oleh peneliti terkait permasalah yang akan diteliti. Sedangkan untuk mendapatkan data sekunder sebagai sumber data tambahan yaitu dengan cara dokumentasi dengan menggunakan handhone untuk mengambil gambar dan merekam suara. Studi kepustakaan yang dilakukan dengan mencatat dan buku-buku, dokumen, dan hal-hal yang berkaitan dengan permasalahan yang diteliti. ${ }^{14}$

Dalam penelitian ini teknik pengolahan data yang digunakan penulis adalah deskriptif kualitatif. Dalam penelitian ini penulis mengunakan analisis deskriptif, yang dimana dalam proses analisis data Miles dan Huberman menyimpulkan bahwa alur kegiatan terbagi menjadi 3 yaitu reduksi data, penyajian data, serta penarikan kesimpulan atau verifikasi.

Adapun yang digunakan oleh peneliti dalam pemeriksaan keabsahan data adalah kriteria kredibilitas dengan teknik pemeriksaan berupa triangulasi yaitu peneliti menghubungkan pemanfaatan sumber dengan membandingkan informasi yang didadapatkan dari waktu yang berbeda. Penggunaan metode pada teknik pengumpulan data, penggunaan pengamat lainnya untuk keperluan pengecekan dan penggunaan teori melalui penjelasan

${ }^{13}$ Adi Isbandi Rukminto, Ilmu Kesejahteraan Sosial dan Pekerjaan Sosial: Pengantar Pada Pengertian dan Beberapa Pokok Bahasan, (Jakarta: FISIP UI Press, 2005), h. $11-20$

${ }^{14}$ Ahmad Tanzeh, Pengantar Metodologi Penelitian, (Yogyakarta: Teras, 2009), h. 54-55 
pembanding yaitu dengan membandingkan teori-teori serta logika kemungkinan yang dapat terjadi dengan data yang diperoleh selama penelitian.

\section{HASIL PENELITIAN}

\section{A. Efektivitas Program Keluarga Harapan (PKH) terhadap Penerima Bantuan di Desa Laliko Kecamatan Campalagian Kabupaten Polewali Mandar}

Berdasarkan dari hasil penelitian tentang efektivitas program keluarga harapan terhadap penerima bantuan PKH di Desa Laliko Kecamatan Campalagian yang diukur dengan menggunakan 5 indikator yang dikemukakan oleh Sutrisno, yaitu pemahaman program, ketepatan sasaran, ketepatan waktu, tercapainya tujuan, dan perubahan nyata, sebagai berikut: ${ }^{15}$

1. Pemahaman Program

Pemahaman program adalah indikator yang digunakan untuk mengetahui sejauh mana pengetahuan masyarakat terhadap Program Keluarga Harapan. Pemahaman program kepada masyarakat dapat dilakukan melalui kegiatan sosialisasi.

Kegiatan sosialisasi maupun pertemuan yang dilakukan oleh Pendamping PKH dengan penerima bantuan PKH dilaksanakan secara rutin sakali dalam sebulan dengan membentuk beberapa kelompok berdasarkan wilayah. Setiap kelompok biasanya terdiri dari 10 sampai 30 orang dan salah satu dari setiap kelompok tersebut akan ditunjuk sebagai ketua kelompok agar memudahkan pendamping dalam melakukan koordinasi. Hal ini sesuai dengan yang disampaikan oleh bapak Anwar selaku pendamping PKH di Desa Laliko Kecamatan Campalagian mengatakan bahwa:

"Kami sebagai pendamping PKH khususnya bagi saya dek, berkewajiban memberikan pemahaman tentang Program Keluarga Harapan di Desa Laliko sekaligus mendengarkan keluhan ataupun permasalahan yang dialami oleh penerima bantuan PKH. Dengan adanya pertemuan atau kegiatan sosialisasi ini, diharapkan agar masyarakat lebih terbuka dengan permasalahan-permasalahan yang dialami selama menjadi penerima bantuan PKH."

Adapun pembahasan ataupun materi yang biasa disampaikan pada saat melakukan sosialisasi yaitu mengenai tujuan dari pelaksanaan $\mathrm{PKH}$, seperti tambahan pernyataan dari Pendamping PKH sebagai berikut:

"Ya biasanya masalah tujuan PKH dek, itu yang paling sering saya ulang untuk disampaikan agar ibu-ibu penerima PKH selalu mengingatnya bahwa bantuan PKH ini untuk pendidikan anak dan kesehatan juga dek. Bisa juga lebih jelasnya dek tentang tujuan PKH bisaki cari di internet, ada semua itu didalam.

\section{h. 125}

\footnotetext{
${ }^{15}$ Edy Sutrisno, Budaya Organisasi, (Jakarta: Kencana Prenada Media Grub, 2007),
} 
Sementara waktu pelaksanaan sosialisasi dilakukan rutin sekali dalam satu bulan berdasarkan penuturan dari pendamping PKH sebagai berikut:

"Tidak menentu tanggalnya dek, tapi biasanya dilaksanan secara rutin setiap bulannya, itupun pertemuannya dek saya bagi perkelompok yang terdiri dari 10-30 orang per dusunnya. Dari sosialisai inilah diharapkan saya bisa dekat dan membantu masyarakat mampu memahami PKH ini dek. ",16

Selain dari hasil wawancara dengan bapak Anwar selaku pendamping PKH di Desa Laliko, berikut adalah hasil wawancara dengan ibu Darmawati tentang pemahaman program selaku penerima bantuan PKH:

"Kalau itu saya cukup mengerti nak. Uang PKH biasanya PKH digunakan untuk penddidikan anak dan kesehatannya juga. Itu yang saya tahu nak”.

Ibu Nurhayati menambahkan pendapatnya yang mengatakan bahwa:

"Iya Alhamdulillah saya mengerti sedikit dek, biasa disampaikan pak anwar uang PKH ini untuk pendidikan dan kesehatan anak". ${ }^{17}$

Berdasarkan hasil Penelitian tersebut pada indikator pemahaman program, sosialisasi maupun komunikasi menngenai Program Keluarga Harapan sudah berjalan dengan baik, sehingga masyarakat mampu memahami apa itu $\mathrm{PKH}$, hak dan tujuan bagi penerima PKH. Dengan kegiatan rutin pertemuan kelompok setiap bulann dapat memudahkan masyarakat untuk berkomunikasi serta menjalin kedekatan terhadap pendamping PKH. Sehingga dengan demikian, indikator pemahaman program ini dapat dikatakan efektif untuk Program Keluarga Harapan di Desa Laliko.

\section{Tepat Sasaran}

Dalam pelaksanaan suatu kegiatan atau program, ketepatan sasaran sangatlah penting. Hal ini berdasarkan teori yang dikemukakan oleh Budiani bahwa ketepatan sasaran program dilihat dari sejauh mana peserta program tepat dengan sasaran yang sudah ditentukan sebelumnya. Sasaran Program Keluarga Harapan yaitu peserta PKH yang telah dinyatakan lolos sebagai penerima bantuan PKH yang diberikan kepada keluarga miskin yang sumber datanya diperoleh dari Desa. Hal tersebut sesuai dengan penjelasan bapak Anwar selaku pendamping PKH di Desa Laliko Kecamatan Campalagian yang mengatakan bahwa:

"Kalau masalah ketepatan sasaran saya rasa sudah tepat dek, karena bantuan PKH ini hanya diberikan kepada keluarga sangat miskin yang datanya diperoleh dari setiap Desa. Kita juga mengadakan pemilhan mengenai masyarakat yang dapat menerima dan yang tidak dapat menerima, karena ada beberapa itu

\footnotetext{
${ }^{16}$ Wawancara dengan Bapak Anwar, Pendamping PKH Desa Laliko, Campalagian 27 Februari 2020

${ }^{17}$ Wawancara dengan Ibu Darmawati dan Nurhayati, Penerima PKH Desa Laliko,Campalagian 27 Februari 2020
} 
penerima bantuan PKH dek walaupun rumahnya bisa dibilang besar namun pendapatannya kurang itu juga bisa kena bantuan"

Adapun beberapa penerima bantuan yang berhasil diperoleh datanya oleh penulis dengan jumlah $30 \mathrm{KK}$ sebagai berikut:

\section{Tabel}

\section{Beberapa Data Penerima Bantuan PKH}

\begin{tabular}{|c|c|c|c|}
\hline No & NAMA & USIA & PEKERJAAN \\
\hline 1 & Nurhayati & 29 & IRT \\
\hline 2 & Muthira & 38 & Pedagang \\
\hline 3 & Hawwah & 53 & IRT \\
\hline 4 & Suhuria & 47 & IRT \\
\hline 5 & Fitriani & 37 & Penjual Ikan \\
\hline 6 & Mina & 35 & IRT \\
\hline 7 & Sapina & 71 & IRT \\
\hline 8 & Nadira & 35 & IRT \\
\hline 9 & Anisa & 44 & IRT \\
\hline 10 & Murdiah & 38 & IRT \\
\hline 11 & Subaeda & 25 & IRT \\
\hline 12 & Syamsinar & 35 & IRT \\
\hline 13 & Sarkia & 46 & IRT \\
\hline 14 & Icci & 30 & IRT \\
\hline 15 & St. Awi & 50 & IRT \\
\hline 16 & Wati & 34 & IRT \\
\hline 17 & Rasna & 35 & IRT \\
\hline 18 & Masdalipa & 48 & IRT \\
\hline 19 & Anita & 36 & IRT \\
\hline 20 & Mayama & 71 & IRT \\
\hline 21 & Fitriani & 39 & IRT \\
\hline 22 & Ruhani & 62 & IRT \\
\hline 23 & Dina & 33 & IRT \\
\hline 24 & Asdawiah & 30 & IRT \\
\hline 25 & Nurti & 52 & IRT \\
\hline 26 & Rusmiati & 48 & IRT \\
\hline 27 & Nurdewi & 54 & IRT \\
\hline 28 & Kindong & 50 & IRT \\
\hline 29 & Ati & 30 & IRT \\
\hline 30 & Darmawati & 43 & Penjahit \\
\hline
\end{tabular}

Berdasarkan hasil pengamatan kami sebagai peneliti selama berada di lokasi penelitian dapat disimpulkan bahwa kebanyakan penerima bantuan PKH yaitu ibu rumah 
tangga (IRT) dan memiliki pekerjaan yang tidak menentu. Mengenai ketepatan sasaran dalam Program Keluarga Harapan di Desa Laliko sudah berjalan dengan baik sehingga indikator tepat sasaran dapat dikatakan efektif.

3. Tepat Waktu

Ketepatan waktu dalam pencairan bantuan PKH sangat diperlukan, mengingat bantuan sosial yang diberikan setiap tiga bulan sekali, kepada masing-masing peserta PKH. Masing-masing stakeholderss (pemangku kepentingan) harus menjalankan tugas dan fungsinya sesuai dengan ketentuan, sehingga dalam pencairan bantuan sosial, khususnya Program Keluarga Harapan dapat tersalurkan tepat waktu. Peran dari masing-masing stakeholderss memiliki keterlibatan dalam pelaksanaan PKH agar dapat berjalan dengan efektif dan efisien. ${ }^{18}$

Adapun masalah waktu penyaluran bantuan Program Keluarga Harapan di Desa Laliko terungkap dari hasil wawancara dengan pendamping PKH yaitu bapak Anwar yang mengatakan bahwa:

"Kalau masalah tanggal pencairan dana PKH dek itu tidak menentu. Dana PKH cair itu 4 kali dalam setahun”.

Berdasarkan dengan hasil wawancara kami dengan pendamping $\mathrm{PKH}$ dapat diketahui bahwa penerimaan dana PKH dalam setahun yaitu sebanyak 4 (empat) kali dan itu diterima setiap tri wulan, sementara waktu penerimaan Januari, April, Juli, dan Oktober berdasarkan dengan apa yang disampaikan oleh bapak Anwar sebagai berikut:

"Tahun 2020 ini dek cairnya dibulan Januari, april, juli, dan Oktober. Tapi, tahap

2 dipercepat masuk dibulan Maret karena faktor wabah virus Corona".

Selain hasil wawancara dengan pendamping PKH, berikut adalah hasil wawancara dari penerima bantuan PKH yaitu ibu Kindong yang mengatakan bahwa:

"Iya nak tepat waktu datangnya. Saya terima biasa 4 kali 1 tahun dan itu uang yang saya terima 3 bulan sekali datangnya".

Hal berbeda disampaikan oleh Ibu Muthira sebagai penerima bantuan PKH, beliau mengatakan bahwa:

"Kalau masalah tepat waktunya nak, yah tepat waktu tapi kadang juga biasa tanggal penerimaan PKH berubah nak. Saya tidak tau kenapa, tapi kalau masalah uang yang saya terima tetap nak tidak ada pengurangan selama ini”.

Berdasarkan hasil penelitian tersebut penulis menyimpulkan bahwa ketepatan waktu pencairan bantuan dana Program Keluarga Harapan di Desa Laliko telah berjalan dengan baik, meskipun tanggal pencairan dananya tidak menentu namun dalam 3 bulan jangka penerimaan dana PKH selalu berjalan dengan baik sehingga indikator tepat waktu bisa dikatakan efektif.

\section{h. $125-126$}

${ }^{18}$ Edy Sutrisno, Budaya Organisasi, (Jakarta: Kencana Prenada Media Grub, 2007), 
"Kalau masalah tepat waktunya nak, yah tepat waktu tapi kadang juga biasa tanggal penerimaan PKH berubah nak. Saya tidak tau kenapa, tapi kalau masalah uang yang saya terima tetap nak tidak ada pengurangan selama ini”.

Berdasarkan hasil penelitian tersebut penulis menyimpulkan bahwa ketepatan waktu pencairan bantuan dana Program Keluarga Harapan di Desa Laliko telah berjalan dengan baik, meskipun tanggal pencairan dananya tidak menentu namun dalam 3 bulan jangka penerimaan dana PKH selalu berjalan dengan baik sehingga indikator tepat waktu bisa dikatakan efektif.

4. Tercapainya Tujuan

Sesuai dengan pernyataan bapak Anwar selaku pendamping PKH di Desa Laliko Kecamatan Campalagian mengatakan bahwa:

"Dengan adanya PKH, diharapkan bisa membantu masyarakat khususnya dalam hal pendidikan an kesehatan dek".

Mengenai pelaksanana PKH di Desa Laliko tentang berjalan dengan baik atau tidak dijelaskan oleh pendamping PKH sebagai berikut:

"Saya rasa sudah berjalan dengan baik dek, saya selalu menekankan dan menyampaikan kepada mereka tentang tujuan PKH. Alhamdulillah juga dek semakin kesini jumlah penerima bantuan semakin berkurang dari yang semula lebih dari 400 orang dan sekarang penerima bantuan PKH sejumlah 371 orang, itu menandakan bahwa adanya PKH ini sangat membantu beban masyrakat dalam memenuhi kebutuhan ekonominya".

Kemudian apakah ada pengawasan yang dilakukan pendamping terhadap penerima bantuan itu sudah ada yang dilakukan sendiri oleh pendamping PKH berdasarkan penuturan yang disampaikan oleh bapak Anwar sebagai berikut:

"Iya ada, kita sebagai pendamping selalu menyampaikan kepada penerima PKH, agar bantuannya digunakan untuk kepentingan pendidikan dan kesehatan anak dan ibu hamil, agar kebutuhan gizi anaknya terpenuhi untuk mencegah stanting. Kami juga menyampaikan ini bukan gaji, semata-mata bantuan dari pemerintah melalui kementrian sosial, agar mengurangi beban dalam keluarganya”.

Apa yang disampaikan oleh bapak Anwar sesuai dengan pengamatan yang kami lakukan selama melaksanakan penelitian di lokasi, hal ini diperkuat oleh ibu Darmawati yang mengatakan bahwa:

"saya bersyukur dengan adanya PKH karena saya bisa membeli keperluan anak sekolah dan kesehatan anak seperti kemarin anak saya yang masih balita bisa ke Puskesmas Campalagian untuk membawa Abyan berobat”.

Selain untuk keperluan pendidikan dan kesehatan mereka juga menggunakan untuk membeli kebutuhan pokok, hal ini diungkapkan oleh ibu Darmawati dan Nurdewi sebagai berikut:

"Ya kalau misalkan sementara kekurangan uang, biasa saya gunakan untuk membeli beras. Tapi sisanya saya belikan anak buku dan keperluan sekolahnya. Ibu 
Nurdewi juga menambahkan pendapatnya yang mengatakan bahwa: "Ya Alhamdulillah nak, saya sangat bersyukur dengan adanya PKH ini apalagi saya kasiang sendiri membiayai anak saya karena suami sudah meninggal nak. Dengan bantuan ini dapat saya membiayai sekolah anak saya”.

Hal tersebut juga disampaikan oleh Ibu Ruhani sebagai penerima bantuan PKH, beliau mengatakan bahwa:

"Syukur Alhamdulillah nak, karena selama ini sudah ada yang membantu saya, dengan bantuan PKH ini saya biasanya pergunakan untuk membeli keperluan di dapur kalau ibu lagi kehabisan uang, saya bersyukur sekali nak sudah bisa terbantu mengurangi pengeluaran sehari hari".

Berdasarkan hasil penelitian tersebut sesuai dengan hasil pengamatan kami dan hasil wawancara yang telah kami lakukan terhadap penerima bantuan dapat disimpulkan bahwa tercapainya tujuan PKH di Desa Laliko sudah berjalan dengan baik, karena sudah membantu mengurangi beban masyarakat miskin walau demikian belum bisa dikatakan efektif seperti yang diungkapkan Darrmawati yang terkadang dana PKH digunkan untuk membeli beras. Hal serupa diungkapkan oleh ibu Ruhani yang menggunakan dana bantuan PKH untuk keperluan didapur. Jadi indikator tercapainya tujuan belum sepenuhnya efektif.

\section{Perubahan Nyata}

Perubahan nyata adalah suatu bentuk perubahan yang dirasakan oleh seseorang atau kelompok terkait pelaksanaan kegiatan atau program yang telah dijalankan. Untuk bisa mengetahui dan mengukur indikator ini, peneliti memfokuskan pada berbagai persepsi dan pandangan masyarakat penerima bantuan PKH. Hal ini diungkapkan oleh ibu Hawwa yang mengatakan bahwa:

"Iya ada perubahan, karena sudah bisa membantu keperluan anak membeli peralatan sekolah untuk pendidikannya, jadi anak-anak juga merasa sangat senang”. Ibu Nurdewi juga menambahkan pendapatnya yang mengatakan bahwa: "Alhamdulillah nak, saya sangat bersyukur dengan adanya PKH ini apalagi saya kasiang sendiri membiayai anak saya karena suami sudah meninggal nak, dengan bantuan ini dapat saya membiayai sekolah anak saya”.

Adapun mengenai masalah pemberhentian PKH nantinya, banyak penerima bantuan yang tidak setuju jika itu dilakukan,hal ini terungkap berdasarkan hasil wawancara dengan beberapa penerima bantuan. Salah satunya yaitu ibu Nurdewi yang mengatakan bahwa:

"Tidak setuju ka itu nak u, saya mau ambil dimana lagi uang untuk menambah biaya sekolah anak karena saya kasiang tidak menentu apa dikerja nak, yah asal ada menambah sedikit nak".

Hal berbeda disampaikan oleh Ibu Rusmiati sebagai penerima bantuan PKH, beliau mengatakan bahwa: 
"Ya itu-itu ji nak, belum ada perubahan tapi alhamdulillah syukur mi tau karena ada sedikit yang membantu dalam mengurangi pengeluaran nak dalam memenuhi kebutuhan sehari-hari"

Berdasarkan hasil penelitian tersebut sesuai dengan hasil pengamatan kami dan hasil wawancara yang telah kami lakukan terhadap penerima bantuan dapat disimpulkan bahwa perubahan nyata yang dirasakan masyarakat di Desa Laliko dengan adanya bantuan PKH ini sudah membantu mereka dalam mengurangi beban pengeluaran khususnya biaya pendidikan dan kesehatan, namun walau demikian masih ada sebagian masyarakat yang merasa belum ada perubahan yang ia alami dalam aspek perekonomian, seperti yang diungkapkan oleh ibu Rusmiati.

Jika diukur dari 5 indikator diatas, maka penulis berpendapat bahwa efektifitas Program Keluarga Harapan (PKH) terhadap penerima bantuan di Desa Laliko belum sepenuhnya efektiv dalam hal pemenuhan tujuan jangka panjang yaitu meningkatkan pendapatan masyarakat dan penanggulangan kemiskinan melalui fasilitas kesehatan dan pendidikan. Namun dilain sisi PKH sudah dapat membantu mengurangi beban masyarakat dalam pemenuhan tujuan jangka pendek (konsumsi langsung).

\section{B. Hambatan dalam pelaksanaan Program Keluarga Harapan (PKH) di Desa Laliko Kecamatan Campalagian Kabupaten Polewali Mandar.}

Berdasarkan dari hasil penelitian diatas yang diukur dengan menggunakan 5 indikator yang dikemukakan oleh Sutrisno, maka penulis menemukan adanya hambatan yang dialami pada pelaksanaan Program Kelurga Harapan yaitu pada indikator tercapainya tujuan dan perubahan nyata sebagai berikut:

1. Tercapainya Tujuan

Berdasarkan hasil pengamatan dan hasil wawancara dilapangan indikator tercapainya tujuan dari PKH belum berjalan dengan baik dikarenakan masih adanya penerima bantuan yang mempergunakan dana yang diterima diluar ketentuan yang dipersyaratkan sebagaimana yang diungkapkan oleh bapak Anwar selaku Pendamping PKH di Desa Laliko sebagai berikut:

"Kami sebagai Pendamping PKH khususnya bagi saya dek, berkewajiban memberikan pemahaman tentang Program Keluarga Harapan di Desa Laliko sekaligus mendengarkan keluhan ataupun permasalahan yang dialami oleh penerima bantuan PKH. Dengan adanya pertemuan atau kegiatan sosialisasi ini, diharapkan agar masyarakat lebih terbuka dengan permasalahan-permasalahan yang dialami selama menjadi penerima bantuan PKH. "

Dari apa yang disampaikan oleh Pendamping PKH bahwa bantuan yang diterima oleh masyarakat lebih ditekankan untuk fasilitas kesehatan dan pendidikan, namun dari hasil penelitian penulis menemukan bahwa sebagian masyarakat mempergunakan dana yang diterimanya untuk kebutuhan pokok misalnya beras dan keperluan dapur. Hal ini dapat dilihat dari beberapa hasil wawancara dengan penerima bantuan sebagai berikut: 
Hasil wawancara dengan ibu Darmawati dan Nurdewi

"Ya kalau misalkan sementara kekurangan uang, biasa saya gunakan untuk membeli beras. Tapi sisanya saya belikan anak buku dan keperluan sekolahnya.

Ibu Nurdewi juga menambahkan pendapatnya yang mengatakan bahwa:

"Ya Alhamdulillah nak, saya sangat bersyukur dengan adanya PKH ini apalagi saya kasiang sendiri membiayai anak saya karena suami sudah meninggal nak. Dengan bantuan ini dapat saya membiayai sekolah anak saya”.

Hasil wawancara dengan ibu Ruhani

"Syukur Alhamdulillah nak, karena selama ini sudah ada yang membantu saya, dengan bantuan PKH ini saya biasanya pergunakan untuk membeli keperluan di dapur kalau ibu lagi kehabisan uang, saya bersyukur sekali nak sudah bisa terbantu mengurangi pengeluaran sehari hari".

Dari hasil wawancara tersebut menunjukkan bahwa adanya penerima bantuan PKH yang mempergunakan dana yang diterimanya untuk keperluan kebutuhan sehari-hari diluar ketentuan yang dipersyaratkan.

2. Perubahan Nyata

Berdasarkan hasil pengamatan dan hasil wawancara dilapangan indikator perubahan nyata dari PKH belum sepenuhnya sesuai dari apa yang menjadi tujuan PKH karena belum bisa meningkatkan pendapatan dan penanggulangan kemiskinan di Desa Laliko. Hal ini dilihat dari hasil wawancara dengan ibu Rusmiati sebagai berikut:

"Ya itu-itu ji nak, belum ada perubahan tapi alhamdulillah syukur mi tau karena ada sedikit yang membantu dalam mengurangi pengeluaran nak dalam memenuhi kebutuhan sehari-hari"

Dari apa yang disampaikan oleh ibu Rusmiati bahwa perubahan nyata yang dialami dalam Program Kelurga Harapan belum bisa dikatakan efektiv sepenuhnya untuk meningkatkan pendapatan masyarakat dan penanggulangan kemiskinan. Namun dilain sisi PKH sudah dapat membantu mengurangi beban masyarakat dalam mengurangi beban masyarakat (konsumsi langsung).

\section{PENUTUP}

\section{A. Kesimpulan}

Berdasarkan dari hasil penelitian dan pembahasan yang telah diuraikan, maka peneliti menarik kesimpulan bahwa:

Efektivitas Program Keluarga Harapan (PKH) terhadap penerima bantuan di Desa Laliko, dapat dilihat dari dari 5 indikator yang dikemukakan oleh Sutrisno, yaitu pemahaman program, tepat sasaran, tepat waktu, tercapainya tujuan, dan perubahan nyata. Maka penulis berkesimpulan bahwa efektifitas Program Keluarga Harapan (PKH) terhadap penerima 
bantuan di Desa Laliko sudah dapat membantu dalam mengurangi beban pengeluaran masyarakat namun demikian PKH ini belum bisa dikatakan sepenuhnya efektiv dalam hal penanggulangan kemiskinan dan meningkatkan pendapatan dilihat dari indikator perubahan nyata yang dialami masyarakat.

Hambatan yang dialami program keluarga harapan di Desa Laliko yaitu pada indikator tercapainya tujuan dan perubahan nyata sebagai berikut dimana belum berjalan dengan baik dikarenakan masih adanya penerima bantuan yang mempergunakan dana yang diterimanya diluar ketentuan yang dipersyaratkan misalnya dana yang diterimanya dibelanjakan untuk membeli kebutuhan pokok seperti beras dan keperluan dapur lainnya karena alasan tertentu. Selain itu, jika dilihat dari hasil penelitian sebagian masyarakat mulai terus menerus mengharapkan bantuan dana PKH sehingga merubah pola pikir masyarakat kurang dalam menciptakan perilaku kemandirian sedangkan $\mathrm{PKH}$ diharapkan mampu mengurangi angka kemiskinan dan meningkatkan pendapatan keluarga miskin.

Pada indikator perubahan nyata dari PKH belum sepenuhnya sesuai dengan apa yang diharapkan dari tujuan PKH karena belum bisa meningkatkan pendapatan dan penanggulangan kemiskinan di Desa Laliko dalam pemenuhan jangka panjang. Namun dilain sisi PKH sudah dapat membantu mengurangi beban masyarakat dalam pemenuhan tujuan jangka pendek (konsumsi langsung).

\section{B.Saran}

Setelah mengemukakan beberapa kesimpulan, maka dalam uraian tersebut akan dikemukakan saran sebagai harapan yang ingin dicapai dalam penelitian ini sebagai berikut:

1. Bagi penerima bantuan PKH hendaknya menggunakan dana yang diterima sebagaimana mestinya berdasarkan dengan ketentuan yang telah ditetapkan, dan juga kepada penerima bantuan untuk tidak hanya terus-menerus mengharapkan dana bantuan PKH sehingga memiliki pola pikir kemandirian dalam memenuhi kebutuhan hidup mereka, karena PKH hanya merupakan bantuan dari pemerintah bukan gaji atau upah sehingga masyarakat bisa memaksimalkan lagi untuk lebih berusaha dalam meningkatkan kesejahteraan hidup mereka.

2. Terkait dengan penggunaan bantuan dana PKH selain untuk kesehatan dan pendidikan, seharusnya keluarga penerima manfaat akan lebih baik lagi apabila dana yang diterimanya digunakan untuk hal-hal produktif misalnya membuka usaha kecil-kecilan untuk mendapatkan hasil atau keuntngan sehingga dapat membantu meningkatkan pendapatan masyarakat miskin.

\section{DAFTAR PUSTAKA}

Al-Qur'an In Word 1.3 dan Terjemahannya.

Al Arif, M. Nur Rianto. Teori Makro ekonomi Islam konsep,teori, dan analisis. Bandung Penerbit Alfabeta, 2010.

Ali, Mohammad Daud Hukum Islam. Jakarta: Rajawali Pers, 2009. 
Astari, Urika Tri dan Argo Pambudi. Efektivitas Program Keluarga Harapan Di Kecamatan Pandak Bantul, Artikel diakses 28 Februari 2020 dari http://journal.student.uny.ac.id.

Budiani, Ni Wayan. "Efektvitas Program Penaggulangan Penangguran Pengangguran Karang Taruna (Eka Taruna Bhakti) Desa Sumerta Kelod Kecamatan Denpasar Timur kota Denpasar" Jurnal Ekonomi dan Sosial INPUT, Vol. 2, No. 1.

Direktorat Jaminan Sosial Direktorat Jenderal Perlindungan dan jaminan Sosial Kementerian Sosial , Pedoman Umum Program Keluarga Harapan, 2013.

Fitriah, Evi. "Implementasi Program Keluarga Harapan (PKH) Dalam Pengentasan Kemiskinan" Skripsi. Serang: Universitas Sultan Ageng Tirtayasa, 2010.

Kementerian Sosial Republik Indonesian, Pedoman Umum Penyelenggaraan Program Keluarga Harapan, 2013.

Meliala, Adrianus. Masalah Kemiskinan dan Kejahatan serta Respon Kebijakan Publik dalam Rangka Mengatasinya, Kebijakan Publik, 2012.

Mustamin, Muh. Khalifah, Metodologi Penelitian Pendidikan. Makassar: Alauddin Press 2009.

Moleong, Lexy J. Metodologi Penelitian Kualitatif, Cet. 22. Bandung: PT Remaja Rosdakarya. 2006.

Peraturan Presiden Republik Indonesia No. 15 Tahun 2010 tentang Percapatan PenanggulanganKemiskinan.http://www.bphn.go.id/data/documents/10pr015.pdf, Diakses (4 April 2020)

Peraturan Menteri Sosial Repulik Indonesia Nomor 1 Tahun 2018 Tentang Program Keluarga Harapan.

Rukmianto, Isbandi . Kesejahteraan Sosial. Jakarta: Raja Grafindo Persada, 2013.

Rukminto, Adi,Isbandi. Ilmu Kesejahteraan Sosial dan Pekerjaan Sosial: Pengantar Pada Pengertian dan Beberapa Pokok Bahasan. Jakarta: FISIP UI Press, 2005.

Strees, Richard M. Efektivitas Organisasi. Jakarta: Lembaga Pendidikan dan Pembinaan Manajemen dan Erlangga, 1980.

Sutrisno, Edy. Budaya Organisasi. Jakarta: Kencana Prenada Media Grub, 2007.

Tanzeh, Ahmad. Pengantar Metodologi Penelitian. Yogyakarta: Teras, 2009. 